„Bohemistyka” 2020, nr 1, ISSN 1642-9893

Tomasz LISOWSKI

DOI: $10.14746 /$ bo. 2020.1 .8

Uniwersytet im. Adama Mickiewicza

\section{Czeski odrodzeniowiec przekłada Pismo Św.}

František Novotný z Luže (1768-1826), duchowny katolicki, pisarz, autor pierwszej gramatyki języka czeskiego napisanej w tym języku, thumacz Ewangelii, współpracujący z luminarzami czeskiego narodowego odrodzenia - z Josefem Dobrovskim i Josefem Jungmannem, do niedawna był postacią niemal zapomnianą w bohemistycznej, a zatem i w slawistycznej refleksji naukowej.

Ten stan rzeczy ostatnio szczęśliwie dla badaczy dziejów zarówno języka, jak i kultury czeskiej, stopniowo ulega zmianie. Bezwzględnie nie do przecenienia w przywracaniu nauce dorobku intelektualnego Františka Novotnego jest opracowanie Josefa Bartonia i Roberta Dittmanna z Uniwersytetu Karola w Pradze, pt. Český obrozenec překládá Písmo. Překladelské dílo Františka Novotného z Luže. Edice Janova evangelia. ${ }^{1}$ Jest to poprzedzona uwagami wprowadzającymi krytyczna edycja Ewangelii wg św. Jana, która oryginalnie wraz z pozostałymi trzema Ewangeliami przełożonymi na język czeski przez Františka Novotnego ukazała się drukiem w przeciągu 1810 i 1811 roku w Pradze i Mladej Boleslavi.

Opracowanie składa się z trzech zasadniczych, merytorycznych czesści:

1. Josef Bartoň, Překlad čtveroevangelia Františka Novotného z Luže

2. Robert Dittmann, Pravopis Novotného čtveroevangelia a úprava textu v predkladáné edici

3. Robert Dittmann na podstawie tekstu przygotowango przez Josefa Bartonia, Edičn část

Edycję tę dopełnia bibliografia, wykaz skrótów i symboli, indeks postaci, wykaz cytowanych miejsc biblijnych, cztery fotografie fragmentów tekstów dziewiętnastowiecznych. Te cześci opracowali wspólnie obaj Autorzy. W zakończeniu czytelnik znajdzie streszczenie w języku angielskim, niemieckim (przekład Roberta Dittmanna) i rosyjskim (przekład Dmitrija Timofeeva).

Informacje o autorstwie poszczególnych części niefortunnie zamieszczone są w tekście ciągłym Wstęu, choć bardziej celowe wydaje się uwidocznienie ich w spisie treści.

1 Josef Bartoň, Robert Dittmann, Český obrozenec překládá Písmo. Překladelské dílo Františka Novotného z Luže. Edice Janova evangelia. Scriptorium: Praha 2018, $160 \mathrm{~s}$.
Jak wykazuje Josef Bartoň w pierwszej części omawianego opracowania, przekład czterech Ewangelii Františka Novotnego, ściśle powiązany z ideami czeskiego odrodzenia narodowego, do początku XXI wieku był zupełnie zapomniany. Przypadek zrzạdził, że Josef Bartoň, przeglądając zasoby biblioteki Wydziału Teologii Katolickiej Uniwersytetu Karola, w roku 2010 natknął się na jego egzemplarz. W dawniejszych (dziewiętnastowiecznych) i nowszych czeskich kompendiach bibliograficznych informacja o dziele Františka Novotnego jest w sposób niezamierzony niepełna, ponieważ wzmiankuje się tam tylko o alternatywnym wobec edycji z lat 1810-1811 wydaniu zawierającym wyłącznie przekład Ewangelii wg św. Mateusza. To nieporozumienie długo nie było prostowane w literaturze naukowej, tym badziej że epoka rzạdów komunistycznych w Republice Czechosłowackiej po 1948 roku nie sprzyjała refleksji nad przekładami biblijnymi. Dzieło przekładowe Františka Novotnego popadło w niepamięć. Przekłamaniom bibliograficznym i wynikającym z nich zapomnieniu tego przekładu Josef Bartoň poświęca wiele uwagi w podrozdziale części pierwszej opracowania, pt. Čtveroevangelium Františka Novotného z Luže knižka se zvláśtnim osudem (s. 18-32). Pisał na ten temat także w odrębnym artykule (Bartoň 2014, s. 183-195).

Przekład czterech Ewangelii František Novotný przygotowywał w zgodzie z ideą odrodzenia czeskiego języka literackiego. Tłumacz był, jak już wspomnieliśmy, nie bez przyczyny autorem rozprawki gramatycznej, pt. Pravidla české reči (1818). Wykazywał więc zainteresowanie zarówno statusem języka czeskiego na przełomie XVIII i XIX wieku, jak i czeskim stylem biblijnym:

Novotného intenzivní odborný zájem o součastnost i historii českého jazyka a o dějin českěho biblického překladu se ovšem výrazně vtělil právě také do jeho vlastního většího překladelského pokusu - českého čtveroevangelia (s. 24)

- zauważa Josef Bartoň i dodaje, że wydany w latach 1810/1811 przekład mieści się w stylistycznym nurcie wyznaczonym przez katolicką translację z początku XVII wieku (wydana w trzech czéściach w latach 1677, 1712 i 1715), a znaną jako Biblia Swietowacławska (Bible svatováclavská) i kontynuowaną przez rewizje tego tekstu dokonanych przez Václava Fortunáta Durycha oraz Františka Faustyna Procházkę zakonników katolickich, którzy w swoich emendacjach wykorzystywali tekst szesnastowiecznej Biblii kralickiej, opracowanej w kregu protestanckiej wspólnoty braci czeskich (s. 17-18) ${ }^{2}$. Właśnie ta renesansowa biblijna translacja była jednym ze źródeł, z których czerpali wzorce współcześni Františkowi Novotnemu odnowiciele czeskiego języka literackiego.

2 Ten ze wszech miar wyjątkowy renesansowy czeski przekład Biblii był ostatnio przedmiotem wnikliwej analizy filologiczno-tekstologicznej ukazującej zmiany modernizacyjne na płaszczyźnie graficznej, gramatycznej i leksykalnej wprowadzane do szesnastowiecznego przekładu w kolejnych jego edycjach aż do XX wieku - zob. Dittmann 2012. 
Przekład Františka Novotnego ma charakter filologiczny jednak nie jest zwykłą kontynuacją tego nurtu stylistycznego - jak zauważa Josef Bartoň - ma on bowiem wiele cech szczególnych, wyróżniajacych go na tle tradycji. Do najważniejszych z nich, omówionych w podrozdziale Charakteristika překladové práce Františka Novotného z Luže (s. 32-64), należą nawiązania do języka przekładu Biblii w języku staro-cerkiewno-słowiańskim (František Novotný korzystał z edycji 1751 roku, znanej jako Biblia Księżny Jelizavety Petrovny - s. 39). Ujawniaja się one głównie w składni i leksyce tekstu, ale także w zakresie fleksji i słowotwórstwa.

Wśród licznych przykładów ilustrujacych to zjawisko wydobytych z tekstu Ewangelii wg św. Jana, znalazło się użycie imiesłowu na -(v)ší, genetycznie kontynuantu dawnego prasłowiańskiego participium perfecti activi $I$, a do przekładu Františka Novotnego przejętego z języka rosyjskiego lub co jest bardziej interesujące w wypadku przekładu Ewangelii, z języka staro-cerkiewno-słowiańskiego (szerzej na ten temat zob. Bartoň 2016, s. 395-428)

Zavedení přechodnikových adjektiv na -(v)ši je nejpozoruhodnější Novotného inovací. [...] Tato kategorie byla totiž uvedena do českého jazykového systému právě za obrození a za jeji zdroj se pokládá ruština. Za nejstarší doklady je považováno šest výskytů v Jungmannové překladu Miltonova Ztraceného ráje, vzniknuvším v letech 1800-1804 [...]. Novotného tlumočení evangelií přitom vzniklo ve stejné době (patrně před rokem 1805) - a obsahuje 54 výskytů adjektiv na -(v)ší v rưzných tvarech a funkcích (nejčastějěś jsou substantivizována nebo živá ruština, nýbrž církevní slovanština (všechny doklady mají oporu v konkrétních místech církevněslovanského biblického textu) (s. 43).

Aprobatywna postawa thumacza na początku XIX wieku wobec staro-cerkiewno-słowiańskich form językowych jako wzorców, mających służyć odrodzeniu się literackiego języka czeskiego, jest oceniana przez Josefa Bartonia - słusznie zreszta jako absolutnie unikalna. Temu zagadnieniu poświęcony jest także odrębny artykuł tego badacza (Bartoň 2018)

František Novotný jawi się także jako znawca języków klasycznych (greki i łaciny), co znajduje odzwierciedlenie w dążności do zbliżenia przekładu czeskiego do języka greckiego oryginału. Tłumacz Ewangelii dostrzegał nieścisłości we wcześniejszych przekładach biblijnych na język czeski, które jego zdaniem w wielu wypadkach niezbyt precyzyjnie oddawały $\mathrm{w}$ jego ojczystym języku sens greckiego oryginału Ewangelii. Za podstawę przekładu, zgodnie z zasadą sformułowaną jeszcze w XVI wieku na soborze w Trydencie, przyjmował łacińska Wulgate (w jej wersji klementyńskiej). Jednak tekst jego przekładu powstawał z uwzględnieniem greckiego oryginału (korzystał z krytycznej edycji greckiego Nowego Testamentu z 1777 roku, którą przygotował Johann Jacob Griesbach). Takie podejście do zadania thumacza tekstu biblijnego na język czeski na tle zastanej tradycji uznać należy za nowoczesne (s. 33). Ponadto styl przekładu czterech Ewangelii na tle wcześniejszych czeskich przekła- dów biblijnych wyróżnia się wprowadzanymi przez tłumacza językowymi formami archaizującymi tekst, np. formy supinum (s. 47).

Część druga omawianego opracowania, pt. Pravopis Novotného čtveroevangelia a úprava textu v predkladáné edici, zawiera bardzo precyzyjnie sformułowane przez Roberta Dittmanna zasady transkrypcji oryginalnego tekstu Ewangelii wg św. Jana z lat 1810-1811, który realizował zasady tak zwanego bratrského pravopisu, ortografii utrwalonej w tradycji czeskiej dzięki edycji Biblii kralickiej. Tak Robert Dittmann formułuje zadanie, jakie przed Autorami omawianego opracowania stanęło:

Cílem naší edice je podat jazykové znění Novotného překladu v hávu současného českého pravopisu. To znamená nesetř́ít jazykové jevy původního překladu, které jsou diferenční, č pravopisné jevy svědčící o stupni adaptace cizích slov, ale zároveň nepřetěžovat našeho čtenáŕc pravopisnými specifiky tisku z počátku předminulého století (s. 65).

Jak się wydaje na podstawie analizy rozwiązań ortograficznych zastosowanych w edycji Ewangelii św. Jana, ten trudny cel został zrealizowany w sposób niebudzący zastrzeżeń

Część trzecia opracowania, Ediční část, zawiera obok tekstu Ewangelii wg św. Jana (Edice Janova ewangelia) także uwagi sformułowane przez Františka Novotnego, pt. Zpráva historická. Obydwa teksty zostały podane czytelnikowi w transkrypcji przeprowadzonej według ustalonych przez Roberta Dittmanna zasad, np.:

1. Na počátku bylo Slovo a Slovo bylo u Boha a Bůh byl Slovo. 2. To bylo na počátku u Boha 3. Všecky věči skrze ně učiněny jsou a bez něho nic není učiněno, což učiněno jest. 4 . V něm život byl a život byl světlo lidí 5. A světlo v temnostech svítí a tmy ho neobsáhly (s. 89).

Odkryty na nowo tekst przekładu czterech Ewangelii na język czeski z początku XIX wieku (pozostałe trzy Ewangelie zostaną wydane krytycznie w najbliższej przyszłości, jak zapowiadają Autorzy opracowania) wniósł do refleksji naukowej lingwistycznej, kulturowej, może także teologicznej - poświęconej fenomenowi czeskiego narodowego odrodzenia niezwykle bogaty i różnorodny materiał badawczy. Słusznie zauważa Josef Bartoň:

Mám za to, že výsledky jeho dosavadního zkoumání [...] mohou v několika aspektech přispět $\mathrm{k}$ prohloubení zatím poměrně málo rozvinuté reflexe dějin české biblické translatolgie i pohledu na procesy utvárení a proměn českého biblického stylu (s. 59).

\section{Literatura}

B a r t o ň Josef, 2014, Zapomenutý překlad pozapomenutého obrozence: české čtveroevangelium Františka Novotného z Luže. „Clavibus unitis”, nr 3, s. 183-195.

B arto ň Josef, 2016, Adjektiva na -(v)ši v evangelnim překladu Františka Novotného z Luže a jejich cirkevněslovanská inspiracje. „Listy filologické”139, nr 3-4, s. 395-428.

B a r t o n̆ Josef, 2018, Церкевнославянское языковое наследие как источник ческого библейского стиля в эпоху начиольного возрождения (Уникальный опыт Франтишека Новотного из Лужи). ,Slověne. International Journal of Slavic Studies” 7, 2, s. 179-198.

D i t $\mathrm{m}$ a n n Robert, 2012, Dynamika textu Kralické bible v české prékladatelské tradici, Olomouc: Refugium. 